\title{
Characteristic of Protein Hydrolyzate Starch of Snakehead Fish (Channa Striata) Head
}

\author{
Sri Udayana Tartar ${ }^{* 1,2}$, M Mahendradatta ${ }^{3}$, Mursalim ${ }^{3}$, Adiansyah ${ }^{3}$ \\ "Post-Graduate Student, Hasanuddin University, Makassar, South Sulawesi, Indonesia \\ ${ }^{2}$ Department of Fishery Product Processing Technology, Pangkep State Polytechnic of Agricultural, Pangkep, \\ South Sulawesi, Indonesia \\ ${ }^{3}$ Department of Agricultural Engineering and Food Technology, Hasanuddin University Makassar, South \\ Sulawesi, Indonesia
}

\begin{abstract}
The making of protein hydrolyzate of snakehead fish head by using spray drying method and it is encapsulated with maltodextrin in which a final product in the form of starch is expected to ease the process of storage and extend the shelf-life of the product. This research was aimed to determine the quality of protein hydrolyzate starch of snakehead fish head with inlet temperature treatment of spray drying $120^{\circ} \mathrm{C}$ and outlet temperature of $80^{\circ} \mathrm{C}$ and the addition of maltodextrin. The design used is independent $\mathrm{t}$-test. It was conducted to compare the average value of sample composition. Experimental data were processed using Statistical Package for Social Science (SPSS) 21.0 for Windows. The best treatment from the research is a comparison of snakehead fish starch and maltodextrin 95\%:5\%. The characteristic of physicochemical of snakehead fish starch as produced in the form of white starch with a yield of $21.35 \%$, white degree L 97.73 , water content $4.52 \%$, ash $7.92 \%$, protein $75.25 \%$, fat $0.60 \%$. Based on this, the protein hydrolyzate of snakehead fish head has the potential to be applied as a flavoring or flavor enhancer and it can be developed as a source of essential amino acids in food products because they contain almost complete essential amino acids.
\end{abstract}

Keywords : Amino Acids, Snakehead Fish Head, Maltodextrin, Spray Drying

\section{INTRODUCTION}

Generally, fish protein hydrolyzate is liquid with a short shelf-life so it must be stored in cold conditions. Storage at low temperatures is a method that has been commonly used to extend the shelf-life of food products that contain high water content (Belitz et al. 2009).Therefore, the second stage of the research is the making of protein hydrolyzate of snakehead fish head by using spray drying method and encapsulated with maltodextrin as the final product in the form of starch is expected to ease the process of storage and extend the shelf-life of the product. Berk (2009) explains the products produced by using spray drying method in the form of brightly-colored powder. Starch-food products contain low water content have several advantages including ease of transportation, storage and wider use. According to Cuq et al. (2011) that food is often made in the form of starch for a variety of reasons, including having a longer shelf-life, ease of transportation, and convenience for consumers. Starch-food products also do not require low temperatures to maintain quality so that it will reduce costs for equipment supply. 
Previously, the study about protein hydrolyzate starch of fish has been conducted by Meiyani et al, 2014. By using shrimp head cooking water as a powdery flavor with the addition of $2.5 \%$ maltodextrin gave the highest glutamic acid by $36.85 \%$. Suharso (2006) made flavor powder of tiger shrimp head (Penaeus monodon) enzymatically as an instant seasoning with $5 \%(\mathrm{w} / \mathrm{v})$ maltodextrin filler. A research on protein hydrolyzate starch has been reviewed by Salamah et al, 2012 using catfish (Clariasgariepinus) as raw material and the supernatant was dried using a spray dryer with an inlet temperature of $120^{\circ} \mathrm{C}$ and an outlet temperature of $80^{\circ} \mathrm{C}$. Djaafar et al, 2017 clarifying good quality pollen can be produced through the process of spray drying at an inlet temperature of $80^{\circ} \mathrm{C}$. Liu. et al, 2015 with CN 104719993 A as a patent invention, the invention of the processing of liquid squid hydrolyzate by an enzymatic method that is added ginger, garlic, and it is concentrated by spray drying for a delicious flavored food seasoning.

It is expected that the study of protein hydrolyzate starch of snakehead fish head by using spray drying method and encapsulation with maltodextrin can ease the process of storage and extend the shelf-life.

\section{METHODS AND MATERIALS}

\section{A. Research Site}

The research was conducted from 2018 to 2019, the making of protein hydrolyzate of snakehead fish head is conducted at the Laboratory of Biochemical and Miniplant, Agroindustrial Program, Department of Fisheries Product Processing Technology of Pangkep State Polytechnic of Agricultural; and for the processing of protein hydrolyzates starch of snakehead fish head by using spray-dryer method was conducted at the Agricultural Central Plant of Plantation Products of Makassar.

\section{B. Materials and Tools}

The materials used are snakehead fish head weighing 3 fish per $\mathrm{kg}$ obtained from Tempe Lake, Wajo district, South Sulawesi, and bromelin enzymes obtained at Delta Malang laboratory as manufactured by Xian Lyphar Biotech Activity of Enzyme 400.000 $\mathrm{u} / \mathrm{g}$ min, maltodextrin, aquades obtained at Intrako Store of Makassar and analysis material.

The tools used in the processing procedure are analytical scales (Sartorius TE 64), ovens (Memmert), shellab vacuum ovens, Kjeldahl apparatus desiccators, waterbath shakers (Wise bath shakers WSB-18), centrifuges (HIMAC CR 21G), and chomameters (Monolta Camera CR-300), filter paper Wadmant 41, cool boxes, knives, electric meat grinders/blenders, fermentation jars, basins, and bottle packaging and caps and tools for chemical analysis uses analytical scales Mettler AE 100, erlenmeyer, funnel, $\mathrm{pH}$ meter (Thermo scientific-USA), Kjeldhal flask, reaction tube, condenser, oven, distillation flask, exicator, porcelain cup burette, digital scale.

\section{Sample Preparation}

Procedure for making protein hydrolyzate of snakehead fish head (Modified by Nurhayati et al. 2007) as follows: snakehead fish is weeded by removing the gills, and washed. After weeding, the head of snakehead fish is separated to be used as raw material for hydrolyzate.

\section{Method}

Protein hydrolyzates of snakehead fish head as obtained from the first stage of the research will be made into protein hydrolyzates of snakehead fish head in the form of starch which are expected to last longer during the storage process. In the second stage of the research, we conduct a comparison of the ratio of snakehead fish head hydrolyzate and the addition of maltodextrin (Snakehead Fish Head HPI: 
Maltodextrin) 100\% was HPKIG:M1 $=$ 97.5:2.5 (b/b) and $\mathrm{HPIM}_{2}=95: 5(\mathrm{~b} / \mathrm{b})$. After adding maltodextrin filler, it is dried with a spray dryer with an inlet temperature of $120^{\circ} \mathrm{C}$ and an outlet temperature of $80^{\circ} \mathrm{C}$. Characteristics of protein hydrolyzate starch of snakehead fish head in physicochemical analysis are water content, ash, protein, fat, and yield and brightness level.

\section{Water Content with Oven Method (AOAC 2005)}

Determination of water content is based on differences in material weight before and after drying. Initially, the empty cup was dried in oven for 30 minutes at a temperature of $105^{\circ} \mathrm{C}$ and then cooled in an exicator for 15 minutes, then weighed 3 - 5 grams of protein hydrolyzate of snakehead fish head and put in a cup then dried in an oven $105^{\circ} \mathrm{C}$ for 6 hours. The cup was cooled in an exicator for 30 minutes and then weighed. Water content is calculated by using a formula:

$$
\text { Water Content }(\%)=\frac{B-C}{B-A} \times 100 \%
$$

\section{Protein Content (AOAC, 2005)}

Protein solution is taken $10 \mathrm{ml}$ and dilute it to $100 \mathrm{ml}$ with distilled water in a flask, then put into Kjeldahl flask $500 \mathrm{ml}$ and $10 \mathrm{ml} \mathrm{H}_{2} \mathrm{SO}_{4}(93 \%-98 \%$ free-N) add 5 grams of mixture $\mathrm{H}_{2} \mathrm{BO}_{3}, \mathrm{Na}_{2} \mathrm{SO}_{4}-\mathrm{HgO}$ for catalyst. Rub thoroughly and continue for 30 minutes. After cooling, wash it in Kjeldahl flask with distilled water then boil again for 30 minutes.

After cooling, adding $140 \mathrm{ml}$ of distilled water, and $35 \mathrm{ml}$ of $\mathrm{NaOH}-\mathrm{Na}_{2} \mathrm{~S}_{2} \mathrm{O}_{3}$ and a few grains of zinc. Then distilled, $100 \mathrm{ml}$ of distillate was stored in Erlenmeyer containing $25 \mathrm{ml}$ of saturated solution of boric acid and a few drops of PP indicator. The solution is obtained with $0.02 \mathrm{NHCl}$.
Ash Content with Gravimetric Method (AOAC, 2005)

As many as 3-5 gr samples is weighed and put in a cup, then burned until there is no smoke. After being put into the furnace, it is burned to gray. Ash is done in two stages, first at $400^{\circ} \mathrm{C}$ and second at $550^{\circ} \mathrm{C}$. After the weight of cup is constant, the cup is then cooled in a desiccator and weighed. The ash content is determined by using a formula:

$$
\text { Ash Content }(\%)=\frac{A}{B} x 100 \%
$$

\section{Fat Content (AOAC, 2005)}

A sample of 2 grams is put in filter paper and in the sleeve. The fat flask that has been weighed then connected with the fat sleeve. Samples and fat solvents (diethyl ether) are put into fat sleeve. The series of fat flask and sleeves are mounted on the Soxhlet extractor which is connected to a recirculation chiller $4^{\circ} \mathrm{C}$. Fat samples were extracted at $60^{\circ} \mathrm{C}$ for $7-8$ hours. The mixture of fat and solvents contained in fat flask is distilled until drying. Fat flask is put in the oven at $105^{\circ} \mathrm{C}$ for 2 hours. The flask is cooled in a desiccator until the weight is constant. Fat content is calculated by using a formula:

$$
\text { Fat Content }(\%)=\frac{W 3-W 1}{W 2} x 100 \%
$$

\section{Color (Hutching JB. 1999)}

Color measurement was made using a colorimeter. The color reading included lightness (L), redness (a) and yellowness (b). The equipment was standardized with a white color standard. 


\section{E. Data Analysis}

The design used is independent $t$-test. It was conducted to compare the average value of sample composition. Experimental data were processed by using Statistical Package for Social Science (SPSS) software 21.0 for Windows (Steel \& Torrie 1993).

\section{RESULTS AND DISCUSSION}

The second stage of the research as the best results from the research of hydrolyzate products of snakehead fish head and it will make into protein hydrolyzate starch with the addition of maltodextrin as a coating material using a drying method using a spray dryer with an inlet temperature of $120^{\circ} \mathrm{C}$ and an outlet temperature of $80^{\circ} \mathrm{C}$. According to Cuq et al. (2011), that food is often made in the form of starch for a variety of reasons, including having a longer shelf-life, ease of transportation, and convenience for consumers. Starch-food products also do not require low temperatures to maintain quality so that it will reduce costs for equipment supply. The physicochemical characteristics of the effect of the percentage of protein hydrolyzate of snakehead fish head and Maltodextrin on protein hydrolyzate starch products of snakehead fish head can be seen in Table 1.

Table 1. Effect of percentage treatment of protein hydrolyzate of snakehead fish head and Maltodextrin of protein hydrolyzate starch product of snakehead fish head

\begin{tabular}{ccc}
\hline & & HPI \\
& HPI Snakehead & Snakehead \\
Composition & Fish Head 97.5 & Fish Head 95 \\
$(\%)$ & $\%$ : Maltodextrin & $\%:$ \\
& $2.5 \%$ & Maltodextrin \\
& & $5 \%$ \\
\hline
\end{tabular}

\begin{tabular}{lcc}
\hline Yield & $19.19 \pm$ & $21.35 \pm 0.24$ \\
& 0.04 & \\
Brightness & $86.0 \pm$ & $97.73 \pm 0.12$ \\
& 0.00 & \\
Water & $5.23 \pm$ & $4.52 \pm 0.13$ \\
& 0.20 & \\
Ash & $7.42 \pm$ & $7.92 \pm 0.24$ \\
& 0.04 & \\
Protein & $55.56 \pm$ & $70.25 \pm 2.26$ \\
& 0.09 & \\
Fat & $0.86 \pm$ & $0.60 \pm 0.07$ \\
& 0.07 & \\
\hline
\end{tabular}

Source: Primary data processed, 2019

\section{A.Content Level of Cork Head Hydrolsat Flour Yield}

Yield content is one of the important parameters in the processing of fishery products which aims to estimate the number of parts of raw materials that can be utilized. According to Anwar and Rosmawati (2013), the percentage of the amount of hydrolyzate product produced to the volume of raw material before hydrolysis is called the yield of hydrolyzate product. Yield value can describe the economic value of a material. The higher of yield value, the higher of economic value because the higher of amount that can be utilized from the material.

Based on Table 1, yield value of protein hydrolyzate starch of snakehead fish head showed protein hydrolyzate of snakehead fish head 95\%: maltodextrin $5 \%$ had a higher yield of $21.35 \%$ compared to protein hydrolyzate of snakehead fish head $97.5 \%$ : maltodextrin $2.5 \%$ had a yield of $19.10 \%$. The study of protein hydrolyzate of snakehead fish head by using liquid protein 
hydrolyzate treatment of snakehead fish head using maltodextrin by spray dryer method with an inlet temperature of $120^{\circ} \mathrm{C}$ and an outlet temperature of $80^{\circ} \mathrm{C}$ seen that the yield obtained was very low, this was caused by liquid hydrolyzate of snakehead fish head with high water content and adding maltodextrin will produce yield according to the amount of maltodextrine used and the working power of spray dryer which still separates the product attaches to the tube. The yield content of protein hydrolyzate starch of snakehead fish head can be seen in Figure 1.

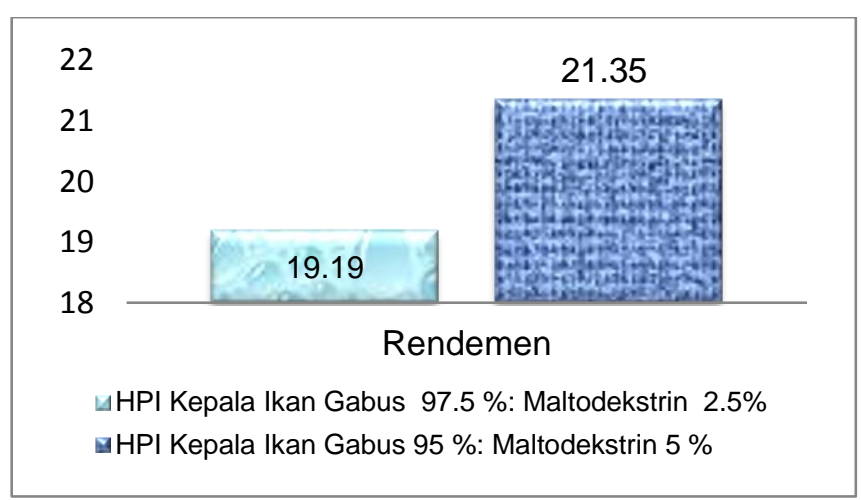

Figure 1. Yield content of protein hydrolyzate starch of snakehead fish head

Based on the results of significance analysis of independent t-test on the yield content of protein hydrolyzate starch of snakehead fish head with the comparison of protein hydrolyzate of snakehead fish head with maltodextrin were difference significantly ( $\mathrm{p}<0.05$ ).Widadi (2011) showed that the yield value of protein hydrolyzate of catfish was $21.16 \%$, it shows a small yield. According to Cucikodana, et al. (2012), the low yield is thought to be due to the effect of drying, where drying is the process of removing or disposing liquid material from a material that includes drying, roasting, evaporation, and others. The end result of drying is material that is free of water (liquid) or contains low amounts of water.

\section{B. Degree of White Cork Head Fish Flour Hydrolsat}

Table 1 protein hydrolyzate starch of snakehead fish head by using a comparison treatment of protein hydrolyzate of snakehead fish head and maltodextrine $97.5 \%: 2.5 \%$, a value of L 86.0 while hydrolyzate of snakehead fish head and maltodextrine 95\%:5\%, a value of L 97.73. The white degree of protein hydrolyzate starch of snakehead fish head can be seen in Figure 2.

White degree indicates the degree of color or brightness of a material, a scale from 0 to 100 ; the greater of L-value, the brighter of sample color. The results of observations of L (lightness), a (redness), and $b$ (yellowness) and white degrees were conducted by using Chromameter.

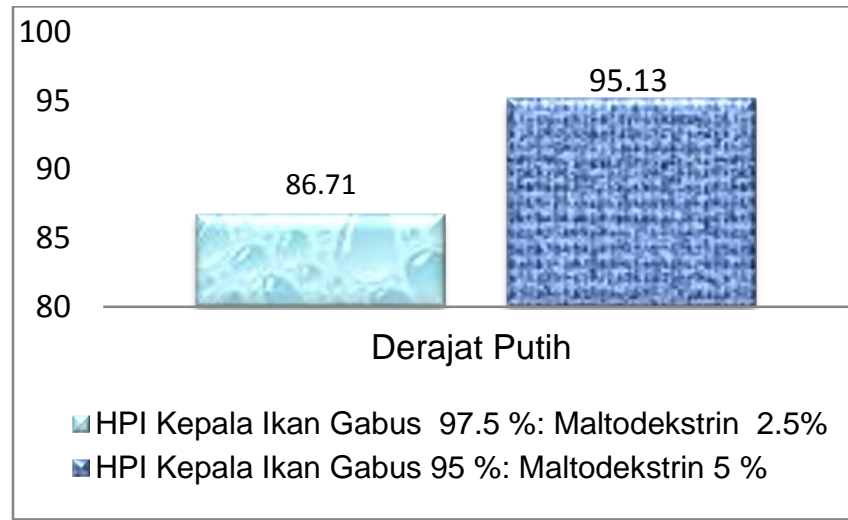

Figure 2. White degree of protein hydrolyzate starch of snakehead fish head

The results of independent $t$-test on the white degree of protein hydrolyzate starch of snakehead fish head with a comparison of protein hydrolyzate of snakehead fish head with maltofrtrin shows a significant difference $(\mathrm{p}<0.05)$. White degree of protein hydrolyzate starch of snakehead fish head as obtained has index value $(>50)$ it indicate a bright color. Pilar and Reyes (2007) explain that the value of yellowness is usually caused by lipids, while 
redness is influenced by protein precipitation. Denaturation or oxidation can also cause high brownish-yellow values in the product. According to Riansyah, et al. (2013), the ability of material to release water from its surface will be greater with increasing air temperature of drier used and the longer of drying process so that the resulting water content is lower. Salamah et al. (2011) states that water content resulting from the drying process by spray drying method is influenced by the temperature of the inlet and outlet, if the temperature used is too high then the risk of protein damage due to heat will also be even greater. The products produced from the spray drying method are brightly colored and porous (Berk 2009).

\section{Proximate Analysis Results of Gabaus Fish Head Hydrolyzate Flour}

Table 1 water content of protein hydrolyzate starch of snakehead fish head as dried with a spray dryer and uses inlet and outlet temperatures $120^{\circ} \mathrm{C}$ and $80^{\circ} \mathrm{C}$, respectively shows the best treatment, namely the ratio of protein hydrolyzate of snakehead fish head and maltodextrine 95\%:5\% has a lower water content i.e $4.52 \%$ compared to protein hydrolyzate of snakehead fish head and maltodextrine 97.5\%: 2.5\% has a moisture content of $5.23 \%$. The results of proximate analysis of the water content of the treatment ratio between protein hydrolyzate of snakehead fish head and maltodextrin as shown in Figure 4 that low water hydrolyzate protein content can be attributed to the high temperature used during the spray drying evaporation process. According to Sanapi (2013), the water content resulting from the drying process by the spray drying method is influenced by the inlet and outlet temperatures. A study of protein hydrolyzate starch of snakehead fish head as obtained from the two treatment comparisons between protein hydrolyzate of snakehead fish head and maltodextrin with spray drying method, obtained lower water content from research conducted by Widadi (2011) and Cholifah (2014) that showed that the value of water content of protein hydrolyzate of catfish was $5.46 \%$ by using spray drying method.

According to Sanapi (2013) states that water content resulting from the drying process by using spray drying method is influenced by the inlet and outlet temperatures. A research by Roslan, et al. (2014) showed that the value of water content of protein hydrolyzate of tilapia was $6.48 \%$ with the addition of $2.5 \%$ alkalase enzyme concentration. The results of independent t-test on the water content of protein hydrolyzate starch of snakehead fish head with a comparison of protein hydrolyzate of snakehead fish head with maltodextrnie were differences significantly $(\mathrm{p}<0.05)$.

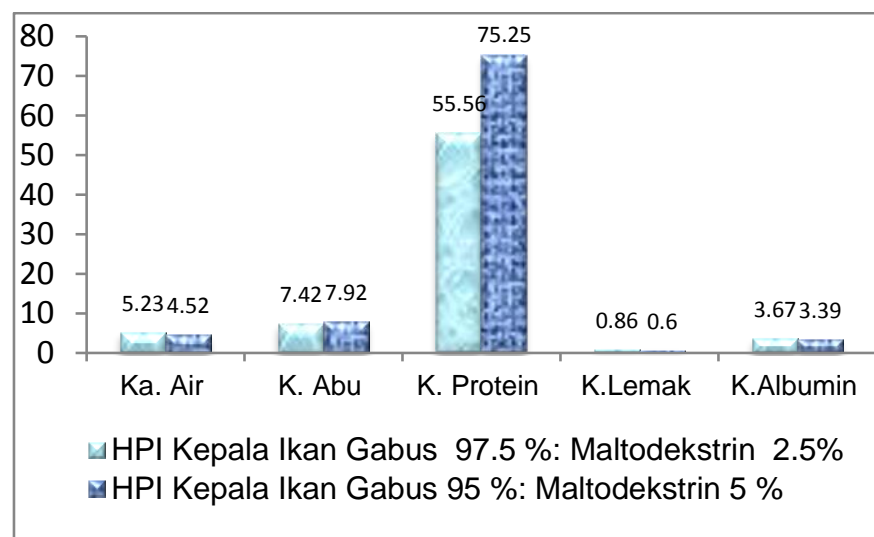

Figure 3. Proximate analysis result for comparison treatment of protein hydrolyzate of snakehead fish head and maltodextrin to protein hydrolyzate starch of snakehead fish head

Most foodstuff consists of $96 \%$ organic matter and water, the rest is mineral elements. The burning process of food to a temperature of $600^{\circ} \mathrm{C}$ will cause organic matter to burn, but the inorganic material does not burn, namely in the form of ash consisting 
of various mineral elements such as $\mathrm{Ca}, \mathrm{Mg}, \mathrm{Na}, \mathrm{P}, \mathrm{K}$, $\mathrm{Fe}, \mathrm{Mn}$ and $\mathrm{Cu}$. Ash content indicates mineral content in foodstuffs (Winarno, 2008). Table 1 the ash content of protein hydrolyzate starch of snakehead fish head dried with spray dryer and inlet and outlet temperature $120^{\circ} \mathrm{C}$ and $80^{\circ} \mathrm{C}$, respectively where the comparison of protein hydrolyzate of snakehead fish head and maltodextrine 97.5:2.5 had higher ash content was $7.42 \%$ and protein hydrolyzate of snakehead fish head and maltodextrine 95:5 has an ash content of $7.92 \%$. Some researchers reported that the ash content of protein hydrolyzate of sardinella by-product had ash content ranging from 12.10 to $25.23 \%$ (Souissi et al. 2007). The results of proximate analysis of ash content for comparison treatment between the protein hydrolyzate of snakehead fish head and maltodextrin to protein hydrolyzate starch of snakehead fish head can be seen in Figure 3. The result of independence t-test analysis on the ash content of protein hydrolyzate of snakehead fish head with the comparison of protein hydrolyzate of snakehead fish head and maltofrtrin have significant differences $(p<0.05)$.

Protein is an essential molecule in the preparation of structure and functional processes of the living things. Proteins consist of amino acid chains that are connected by peptide bonds to form a variety of complex structures (Vaclavik and Christian, 2008). Table 1 the highest protein levels of protein hydrolyzate starch of snakehead fish head is a comparison of protein hydrolyzate of snakehead fish head and maltodextrine 95\%:5\% has $75.25 \%$ compared to protein hydrolyzate of snakehead fish head and maltodextrine $97.5 \%: 2.5 \%$ has $50.56 \%$, the high or low protein value can be influenced by the amount of water content lost (dehydration) from the material. The protein value as measured will be even greater if the amount of water lost is greater. The results of proximate analysis of protein content for comparison treatment between protein hydrolyzate of snakehead fish head and maltodextrin to protein hydrolyzate starch of snakehead fish head can be seen in Figure 3. Studies conducted by several researchers reported that protein content of protein hydrolyzate of catfish $35.6 \%$ (Amiza et al. 2013) is lower than the study of protein hydrolyzate for snakehead fish head. Protein hydrolyzate of snakehead fish head and maltodextrine 95\%:5\% with protein content $75.25 \%$ almost close to commercial fish protein hydrolyzate value that is $73-75 \%$ (International Quality Ingredients, 2011) and according to the Food and Agricultural Organization (2011) that protein hydrolyzate of snakehead fish head has a protein content of less than $80 \%$ included in type $\mathrm{B}$ protein content that meets the requirements as type B hydrolyzate. Nurhayati et.al (2007) states that protein content as measured in protein hydrolyzate of fish as a dissolved protein molecule. According to Bahalwan (2011), the increase in protein content is caused by the decrease in water content in the sample. Reducing the water content of foodstuff will increase compounds such as protein and minerals, but vitamins and dyes in general will be reduced. The result of independent $\mathrm{t}-$ test for protein content of protein hydrolyzate starch of snakehead fish head with a comparison of protein hydrolyzate of snakehead fish head with maltodextrin shows significant difference $(p<0.05)$.

Fat molecules consist of fatty acids and glycerol. Fats are contained in each type of foodstuff, but at different levels. Fat is also deposited in the tissues of several types of animals and organs of several types of plants. Fats are included in a group of compounds called lipids, and generally have insoluble properties in water (Belitz et al. 2009). Based on Table 1 it can be seen that the highest fat content of protein hydrolyzate of snakehead fish head is the comparison 
of protein hydrolyzate and maltodextrin $95 \%: 5 \%$ is $0.60 \%$ compared to protein hydrolyzate of snakehead fish head and maltodextrin $97.5 \%: 2.5 \%$ is $0.86 \%$. The results of proximate analysis of fat content for comparison treatment between protein hydrolyzate of snakehead fish head and maltodextrin to protein hydrolyzate starch of snakehead fish head can be seen in Figure 4. Studies of protein hydrolyzate starch of snakehead fish head meet the standards of commercial fish protein hydrolyzate (Sanapi, 2013), namely less than $19-22 \%$. This is due to the working process of bromelin enzyme which separates fat after being hydrolyzed. According to Nurhayati, et al. (2014), shows that fat content in hydrolyzate products is influenced by the characteristics of hydrolysis material used and the process of fat separation after hydrolysis. The process of separating fat after hydrolysis is done by filtering method using filter paper. According to Purbasari (2008), a decrease in fat content in fish protein hydrolyzate products is caused by the enzymatic hydrolysis process which changes the structure of fish tissue very quickly, where myofibril protein is greatly reduced during hydrolysis process, whereas the muscular cell membrane system looks relatively resistant to damage. During the hydrolysis process, these membranes tend to gather and form insoluble bubbles, resulting in loss of lipid membrane. Fat content of protein hydrolyzate starch of snakehead fish head is lower than fat content of commercial protein hydrolyzate namely 19-22\% (International Quality Ingredients, 2011). The treatment of protein hydrolyzate of snakehead fish head and $95 \%: 5 \%$ is $0.60 \%$ meets the requirements for type $\mathrm{A}$ hydrolysates because it has a fat content of less than $0.75 \%$ (FAO, 2011). Nilsang et al. (2005) states that protein hydrolyzate products which have low fat content are more stable against fat oxidation reactions during storage compared to fish protein hydrolyzate with high fat content. Fat molecules consist of fatty acids and glycerol. The results of independent t-test analysis on the fat content of protein hydrolyzate starch of snakehead fish head with a comparison of protein hydrolyzate with maltofrtrin were difference significantly $(\mathrm{p}<$ 0.05).

\section{Conclusion}

The best treatment from the research is a comparison of snakehead fish starch and maltodextrin 95\%:5\%. The characteristic of physicochemical of snakehead fish starch as produced in the form of white starch with a yield of $21.35 \%$, white degree L 97.73 , water content $4.52 \%$, ash $7.92 \%$, protein $75.25 \%$, fat $0.60 \%$. Based on this, the protein hydrolyzate of snakehead fish head has the potential to be applied as a flavoring or flavor enhancer and it can be developed as a source of essential amino acids in food products because they contain almost complete essential amino acids.

\section{REFERENCES}

[1]. Amiza MA, Ow YW, Faazaz AL. 2013. Physicochemical properties of silvercatfi sh (Pangasius sp.) frame hydrolysate. International Food Research Journal 20(3): 1255-1262.

[2]. Anwar, L. O. dan Rosmawati. 2013. Characteristics of Tambelo (Bactronophorus sp.) Hydrolyzed Protein Hydrolyzed Using Papain Enzyme. Biogenesis1(2): 133-140.

[3]. Association of Official Analytical Chemist. 2005. Official Method of Analysis of The Association of Official Analytical of Chemist. Arlington, Virginia. USA: Association of Official Analytical Chemist, Inc.

[4]. Bahalwan, F. 2011. Effect of Salt Content and Storage Duration on Quality of Mounted Microbiology as Material of Learning Modules for the Formed Craftsman Society. [Bimafika, 
2011，3， 2992-297]. University Darussalam Ambon, Ambon.

[5]. Belitz HD, Grosch W, Schieberle P. 2009. Food Chemistry. Germany: Springer-Verlag.

[6]. Berk Z. 2009. Food Proces Engineering and Technology. New York:Academic Pr.

[7]. Cucikodana, Y, A. Supriadi, dan B. Purwanto. 2012. Effect of Boiling Temperature Differences and $\mathrm{NaOH}$ Concentration on Quality of Cork Fish Bone Powder (Channastriata). Fishtech, 1 (1): 91-101.

[8]. Cuq, B., E. Rondet, J. Abecassis. 2011. Food Powders Engineering, Between Knowhow and Science: Constraints, Stakes and Opportunities, Powder Technology, 208 : 244-251

[9]. Cholifah. 2014. Production and Characterization of White Snapper Viscera (Lates calcarifer). [Thesis]. Department of Aquatic Product Technology, Faculty of Fisheries and Marine Sciences, Bogor Agricultural University, Bogor

[10]. Djaafar T. F., Umar .S dan Anggara .A.2017 Effect of Maltodextrin Addition and Spray Dryer Inlet Temperature on the Physical-Chemical Characteristics of Pollen Pollen (Canavalia virosa) AGRITECH, Vol. 37, No. 3, Agustus 2017, Hal. 334-342 DOI: http://doi .org/10.22146/ agritech. 10446 ISSN 0216-0455 (Print), ISSN 2527-3825 (Online) Tersedia online di https://jurnal. ugm.ac.id/agritech

[11]. Food and Agricultural Organization. 2011. Fish Protein Concentrate. http://www. fao.org/. [14 November 2016].

[12]. Meiyani ,D. N.A.T. , Putut H. R dan Apri D. 2014. Utilization of White Shrimp Head Decoction (Penaeus merguiensis) as Flavor in Powder Form with the addition of Maltodextrin. Journal of Processing and Biotechnology of Fisheries Products Volume 3, Number 2, Tahun 2014, Halaman 67-74 Online di : http:// www ejournal -s1.undip .a c.id/index.php/jpbhp
[13]. Suharso (2006), Suharso, T. 2006. Enzymatic Making of Flavored Prawn Head Powder (Penaeus monodon) as an Instant Seasoning for Cuisine. [Thesis]. The Institute of Agriculture Bogor. Bogor

[14].Salamah dkk, 2012 Salamah, E., Nurhayati,T., Widadi, I. R. 2012. Manufacture and bacterial hydrolysis of protein from catfish (Clariasgariepinus) using the papain enzyme. JPHPI, Volume 15 Number 1

[15]. Steel RGD, Torrie JH. 1993. Statistics Principles and Procedures, A Biometric Approach. 2nd ed. Jakarta: Gramedia Main Library

[16]. Salamah, E., Nurhayati, T., Widadi, I. R. 2012. Preparation and Aracterization of Protein Hydrolyzate from Dumbo Catfish (Clariasgariepinus) Using the Papain Enzyme. JPHPI, Volume 15 Number 1.

[17]. Salamah E, Nurhayati T, Widadi IR. 2011. Making and characterizing protein hydrolyzate from African catfish (Clarias gariepinus) using the enzyme papain. Indonesian Fisheries Product Processing Journal 15 (1): 9-16

[18]. Sanapi, C. H. 2013. Characteristics of Functional Hydrolyzate Protein Catfish (Clarias gariepinus). [Thesis]. Department of Aquatic Product Technology, Faculty of Fisheries and Marine Sciences, Bogor Agricultural University, Bogor.

[19]. Souissi N, Bougatef A, Ellouz YT, Nasri M. 2007. Biochemical and functional properties of Sardinella (Sardinella aurita) by product hydrolisates. Food Technol Biotechnol 45(2): 187-194.

[20]. Hutching JB. 1999. Food Color and Appearance.Chapman and Hall Food Science Book.Gaithersburg Maryland (USA): AspenPublishers Inc.

[21]. International Quality Ingredients. 2005. Product specification: fish protein hydrolysate. http://www.IQI.com [16 Juni 
[22]. Liu,H., Chunyan,L., Lu,Y., Jiang , Chenxiao, E., Gaofeng,Y., and Xubo, F. 2015 . Application Method of Hydrolysate after Squid Tentacles Peeled through Enzymic Method and SeafoodFlavor Seasoning Prepared through Method. Paten CN104719993.

[23]. Nurhayati et al. (2007) Nurhayati T, Salamah E, Hidayat T. 2007. Characteristics of the protein hydrolyzed cellar (Caranx leptolepis) which are enzymatically processed.Bul Aquatic Product Technology 10 (1): 23-34

[24]. Nurhayati, et al. (2014, E. Salamah, Cholifah, and R. Nugraha. 2014. Optimization of the Process of Hydrolysis of White Snapper Offal. JPHPI, 17 (1): 42-52.

[25]. Nilsang S, Lertsiri S, Suphantharika M, Assavanig A. 2005. Optimization of enzymatic hydrolysis of fish soluble concentrate by commercial proteses. J Food Engineering 70: 571578.

[26]. Pilar T, Reyes P. 2007. Simultaneous application of transglutaminase and high pressure to improve functional properties of chicken meat gels. Food Chem. 100(1):264-272.

[27]. Purbasari, D. 2008. Production and Characterization of Protein Hydrolyzate From Ngur Mas Shells (Atactodea striata). [Thesis]. Fisheries Product Technology Study Program, Faculty of Fisheries and Marine Sciences, Bogor Institute of Agriculture, Bogor.

[28]. Riansyah, A, A. Supriadi, and R. Nopianti. 2013. The Effect of Temperature and Drying Time Differences on the Characteristics of Trichogast erpectoralis Salted Fish Using Oven. Fishtech, 2 (1): 53-68.

[29]. Roslan, J.K.F. M. Yunos, N. Abdullah, S. Mazlina, dan M.Kamal. 2014. Characterization of Fish Protein Hydrolysate From Tilapia (Oreochromis niloticus) By-Product. Agriculture and Agricultural Procedia, 2: 312-319.
[30]. Vaclavik VA, Christian EW. 2008. Essential of Food Science. Ed ke-3. New York: Springer

[31]. Widadi, I.R. 2011. Preparation and Characterization of Protein Hydrolyzate from Dumbo Catfish (Clarias gariepinus) Using Papain Enzyme [Thesis]. IPB's Faculty of Fisheries and Marine Sciences.

[32]. Winarno FG. 2008. Food Chemistry and Nutrition. Bogor: M-Brio Press.

\section{Cite this article as :}

Sri Udayana Tartar, M Mahendradatta, Mursalim, Adiansyah, "Characteristic of Protein Hydrolyzate Starch of Snakehead Fish (Channa Striata) Head", International Journal of Scientific Research in Science and Technology (IJSRST), Online ISSN : 2395-602X, Print ISSN : 2395-6011, Volume 6 Issue 5, pp. 171-180, September-October 2019. Available at doi : $\quad$ https://doi.org/10.32628/IJSRST196519 Journal URL : http://ijsrst.com/IJSRST196519 